\title{
Microbial analysis and virulence genes detection of milk preserved using heat-assisted pulsed electric field
}

\author{
Suci Yuliangsih ${ }^{1,2}$, Diana Elizabeth Waturangi ${ }^{2^{*}}$ (D) and Yogiara ${ }^{2}$
}

\begin{abstract}
Objective: Microbial analysis in milk preserved using heat-assisted Pulsed Electric Field (PEF) need to be assessed. In this study we analyze the microbial quality and virulence-associated genes in milk samples preserved using heatassisted PEF from several producers in Indonesia.

Results: Milk samples were collected consisting of raw milk, milks taken after the heating, PEF, mixing, cooling, and packaging. Microbiological and Polymerase Chain Reaction (PCR) detection for virulence genes were performed. Heat-assisted PEF treatment gave 2.7-7.47 log reduction for TPC; 1.6-2.56 log reduction for MPN number; 3.13-6.48 $\log$ reduction for $S$. aureus; and for $B$. cereus there was an increase of $0.76 \mathrm{log}$ and a reduction of $0.46 \mathrm{log}$. While milk samples from thermal pasteurization gave log reduction numbers of TPC, MPN, and $S$. aureus respectively $5.28 ; 2.56$; and 4.73 , for $B$. cereus was increasing $2.4 \mathrm{log}$. Producer $C$ performed the best results with significant reduction compared with others $(p<0.005)$. There were no colonies of $L$. monocytogenes found in all of the samples. PCR results showed that milk samples possessed virulence genes 17.5\% (10/57) of invA genes, 54.4\% (31/57) of nheA genes, 68.4\% (39/57) of cytK genes, 38.6\% (22/57) of nuc genes, 63.2\% (36/57) of iles genes, while hly and actA genes were not detected.
\end{abstract}

Keywords: Microbial analysis, Virulence genes, PEF, Milk, Heating

\section{Introduction}

Globally, billions of people are at risk of foodborne diseases (FBDs) [1]. Milk and dairy products can harbor a variety of microorganisms and can be important sources of FBDs [2]. Microbes that may be present in milk can include pathogens, spoilage organisms, organisms that may be conditionally beneficial [3]. Microbes that contaminate milk have some virulence genes such as: Salmonella spp. with invasion A $(\operatorname{inv} A)$ gene that responsible for initiating infection [4]; B. cereus can produce enterotoxin, Non Hemolytic Enterotoxin (NHE) and Cytotoxin

\footnotetext{
*Correspondence: diana.waturangi@atmajaya.ac.id

2 Faculty of Biotechnology, Atma Jaya Catholic University of Indonesia,

Jalan Jenderal Sudirman 51, Jakarta 12930, Indonesia

Full list of author information is available at the end of the article
}

$\mathrm{K}$ encoded by nheA cytK [5]; L. monocytogenes contains listeriolysin which lyses erythrocytes and other cells, it encoded by $h l y$, while $a c t A$ gene to promote intracellular motility [6]. For the $n u c$ gene encoded staphylococcal thermonuclease is a biofilm inhibitor that degrades environmental DNA (eDNA) associated with biofilm; [7], while some Staphylococcus resistance to mupirocin which inhibits protein synthesis by binding to the bacterial isoleucyl-tRNA synthetase enzyme which is encoded by the ileS gene [8].

Non-thermal preservation methods have a minimal impact on the sensory, quality and nutritional status of food. Pulsed Electric Field (PEF) provides an alternative choice for various food products particularly for liquid foods, which provide better preservation and maintenance of fresh-like quality aspects of food [9]. 
During milk preservation, contamination could be happened from bulk tank milk occurs during and after milking; thermoduric bacteria in milk that can arise from the soil, bedding, feed, dust, all of which contaminate cow's teats, and also occur from deposits on milking equipment [10].

PEF treatment is defined as applying a short burst of high voltage electric pulses in the range of $20-80 \mathrm{kV} \mathrm{cm}^{-1}$ placed between two electrodes is involved in pulsed electric fields processing. Treatment time of PEF lasts in microseconds; thus, the increase in treatment temperature during PEF processing is minimized. The application of high voltage results in an electric-fields that causes microbial inactivation [11]. Some PEF instruments have been developed in Indonesia and the microbial quality had been assessed and showed that PEF could reduce total microbe from $7.8 \times 10^{5} \mathrm{CFU} / \mathrm{ml}$ to $3.09 \times 10^{2} \mathrm{CFU} /$ $\mathrm{ml}(49.48 \mathrm{kV} ; 270 \mathrm{~s})$ [12]. While Muslim et al.[13] stated that PEF can reduce the number of S.aureus in fresh milk from $1.6 \times 10^{3} \mathrm{CFU} / \mathrm{ml}$ to $1.157 \times 10^{3}-3.97 \times 10^{2} \mathrm{CFU} /$ $\mathrm{ml}$. However, microbial analysis for other bacteria as well as determination of their virulence potential, which are commonly associated with milk contamination is very limited. Milk preserved using PEF in Indonesia are consumed daily by some children. Pathogenic microbial contamination of milk may lead to infection in pediatric population [14]. Indonesian Food and Drug Authority [15] has determined the maximum limit of microbiological contamination for pasteurized milk, which include: total plate count (TPC), Enterobacteriaceae and Salmonella respectively $\mathrm{m}=10^{4}, \mathrm{M}=10^{5}$ colony $/ \mathrm{ml} ; \mathrm{m}=<1$ $\mathrm{MPN} / \mathrm{ml}, \mathrm{M}=5 \mathrm{MPN} / \mathrm{ml}$; and negative $/ 25 \mathrm{ml}$. This research aimed to analyze the microbiological hazards at small-medium enterprises from raw milks to packaged milks after that detected the virulence-associated genes of the isolates.

Microbiological hazards analysis of PEF milk is still limited in Indonesia. Thus, this study would be useful for FBDs prevention, support microbiological risk assessment, policy-making, and improvement the process at SMEs.

\section{Main text \\ Methods \\ Bacterial strains and culture medium}

Bacterial strains used in this study were Salmonella Typhimurium (ATCC 14028), Listeria monocytogenes (ATCC 7644), Staphylococcus aureus (ATCC 25923), Bacillus cereus (ATCC 11778), Bacillus subtilis (ATCC 6633 NCTC 10400), and Escherichia coli (25922) (Indonesian FDA Culture Collection). All of the strains were grown in Tryptone Soya Broth at $37{ }^{\circ} \mathrm{C}$ for $24 \mathrm{~h}$. Grown cultures were streaked on selective medium agar respectively, Xylose Lysine Desoxycholate Agar, PALCAM Agar, Baird Parker Agar, Mannitol Egg Yolk Polymixin Agar, and Eosin Methylene Blue Agar to verify the purity. Single colonies were picked from agar plates and streaked on Tryptone Soya Agar then incubate over night at $37^{\circ} \mathrm{C}$.

\section{Sampling}

A total 57 milk samples were taken from four small medium enterprises at A, B, C, and D located in Jakarta and East Java, Indonesia, for each process including: raw milk, heated milk, PEF milk, cooled milk, and packaged milk. Samples were poured into sterile tubes then chilled and brought immediately to the laboratory for further assays. UHT milk was also taken from the supermarket to be tested in the laboratory as a comparison.

\section{Microbiological analysis}

Microbiological analyses were performed to confirm the presence of pathogenic bacteria. $25 \mathrm{ml}$ of samples were suspended in $225 \mathrm{ml}$ of bacterial medium to obtain a 1:10 dilution and treated based on SNI 2897:2008 [16] and ISO 7218:2007 [17] for testing TPC, S. aureus, L. monocytogenes, Salmonella spp; ISO 21528-1:2004 [18] for testing MPN Enterobacteriaceae and SNI ISO 7932:2012 [19] for testing B. cereus. Data were analyzed using variance analysis if the ANOVA test showed statistically significant difference, then Tukey test was further carried out to determine whether there was a difference between each treatment.

\section{Molecular analysis}

DNA extraction was done using ZymoBIOMICS ${ }^{\mathrm{TM}}$ DNA Mini Kit method for milk samples and the boiling method for bacteria isolates. Five specific colonies were selected randomly using sterile loop and streaked on BHI agar, then incubate at $37^{\circ} \mathrm{C}$ for $24 \mathrm{~h}$. Colonies were picked and put into $500 \mu \mathrm{l}$ of sterile $\mathrm{NaCl}$. Samples were boiled for $15 \mathrm{~min}$, then centrifuged at $12.000 \mathrm{rpm}$ for $5 \mathrm{~min}$. The supernatant was taken and transferred into a new tube. DNA concentration was measured using BioDrop Duo UV/Vis spectrophotometer, and then the supernatant was used as a DNA template for PCR detection [20]. A preliminary study was done to optimize PCR condition and specificity test. PCR amplification was performed using Go Taq Green Master Mix (Promega, USA). PCR reactions and protocol were informed in Additional file 1: Table S1.

\section{Results}

\section{Microbiological analysis}

Results showed that combination of heating $\left(50-74{ }^{\circ} \mathrm{C}\right.$ for approximately $5 \mathrm{~s}$ ) and PEF process could reduce log 
cycles number of TPC, MPN, S. aureus and B. cereus respectively at producer $\mathrm{A}(7.47,2.56,4.67,0.46)$; producer B $(2.86,1.6,6.48,-0.76)$; producer $C(2.7,1.68$, $3.13,0)$; and producer D (thermal pasteurization) (5.28, $2.56,4.73,0)$; while in negative control (sample E) there were no microorganisms growing in the media.

\section{Statistical analysis}

Statistical analysis was done by using quantitative microbiological results from final products. The results showed that independent variables (pasteurization process) have a statistically significant effect on the dependent variables in mean interest $(p<0.001)$ between among dependent variables. Then it was continued with LSD and Tukey analysis. Multiple comparisons showed that the error term was 0.737 and the mean difference was significant at the 0.05 level. It was described in more detail in subset on Additional file 2: Table S2.

Based on Additional file 2: Table S2, milk processing established at producer $\mathrm{C}$ showed the best results compare with other producers based on significance result and also showed the lowest total number of microorganism found from TPC assay for S. aureus and B. cereus compared with other producers.

\section{Molecular analysis}

Some virulence genes were detected in processed samples and also final products of producers A, B, C and D (Fig. 2). PCR results revealed that milk samples possessed virulence genes $17.5 \%(10 / 57)$ invA genes in raw milk and packaged flavor milk; $54.4 \%$ (31/57) nheA genes in milk samples after heating, PEF, cooling and packaging process; $68.4 \%$ (39/57) cytK genes in all milk samples; $38.6 \%$ $(22 / 57) n u c$ genes in raw milk, after heating and packaging process; $63.2 \%(36 / 57)$ ileS genes in raw milk, after heating, PEF and packaging process; while hly and actA genes were not detected in this study. Packaged milk with flavour gave the highest detection of $i n v A$, nheA, and $c y t K$. This step could be identified as a contamination source in milking production using PEF techniques.

\section{Discussion \\ Microbiological analysis}

Based on our result combination of heating and PEF could reduce number of bacteria (Fig. 1). In the framework of the hurdle concept, several researches have been focused on the use of PEF in combination with heat and/ or antimicrobials to increase its efficacy [21]. In another trial, PEF processing of milk was combined with heat treatment up to $55-60{ }^{\circ} \mathrm{C}$ and a significant reduction was observed in the microbial load [9]. The experiment of Hawa et al.[22] showed that the highest $E$. coli inactivation was a combination of thermal $\left(70{ }^{\circ} \mathrm{C}, 15 \mathrm{~s}\right)$ and PEF $(100 \mathrm{kV}, 24.37 \mathrm{~s})$ can reduce E. coli $2.5 \log$ cycles in fresh milk.

Salmonella can enter milk from raw or improperly pasteurized milk and eggs, as well as other food have also been associated with salmonellosis or causing diseases

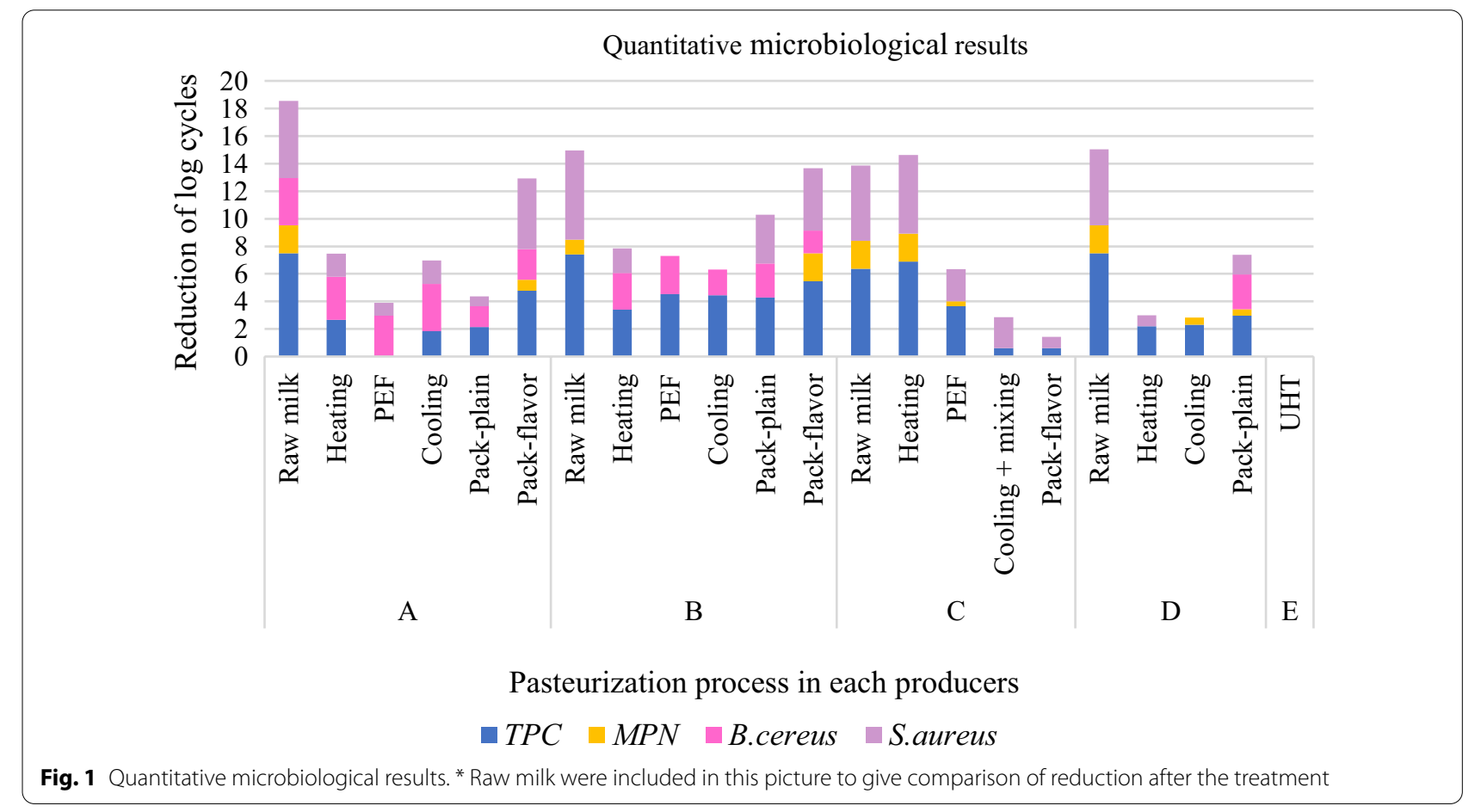


[23, 24]. Kamana et al. [25] stated that $21.4 \%$ of the boiled milk sold from milk shops was Salmonella positive, clearly indicating as Post Pasteurization Contamination (PPC). Several Gram-negative bacteria, when introduce as PPC, can grow rapidly at refrigeration temperatures around $6{ }^{\circ} \mathrm{C}$ and can increase bacterial contamination above $20,000 \mathrm{CFU} / \mathrm{ml}$ and spoilage that can be detected sensorily within 7 to $10 \mathrm{~d}$ of processing [26].

Figure 1 showed the number of $S$. aureus increased after packaging step. Contamination could happen during the addition of flavor and packaging steps. B. cereus have the ability to form spores when subjected to harsh environment, extreme $\mathrm{pH}$ values or nutrition lacking environment. Listeria is one of the most resistant vegetative cells populations to a PEF treatment at neutral $\mathrm{pH}$ while $S$. aureus can produce a toxin in improperly stored food that, if ingested, will produce mild to severe symptoms [10, 27-29].

PEF protocols from each producers showed that not necessarily effective in destroying all kinds of milk microbes. It has been observed that there is a great variation in the sensitivity of different strains of the same species of bacteria to PEF treatment [23]. Furthermore, Gram-positive bacteria showed more resistance to PEF than Gram-negative [24], Salmonella and E. coli are more susceptible to PEF as compared to Listeria and Bacillus species. The presence of fat and protein moieties limits the adeptness of PEF in whole milk because these molecules protect bacterial cells during treatment [9]. The microbiological quality of dairy products reflects good hygienic practices during the dairy milking process [30].

\section{Molecular analysis}

Salmonella spp. gene invA was detected in colonies of raw milk and some final products at producer $\mathrm{B}$ (Table 1). Jasim et al. [31] found $100 \%$ virulence genes include inv $A$ gene in milk samples: raw milk (cow), raw milk (street vendors and shops); and processed milk (pasteurized milk); Omar et al. [32] detected both $i n v A$ and stn genes in all representative Salmonella serovar isolated from milk and dairy products; and Liwan et al. [30] stated that virulence factor $i n v A$ were detected in all raw milk samples.

Bacillus cereus produces three secreted pore-forming cytotoxin $\mathrm{Hbl}$, Nhe and cytK have been implicated as the causative agents of diarrheal disease [33, 34]. The non-hemolytic enterotoxin (Nhe) is responsible for diarrhea [35]. Both $n h e A$ and $c y t K$ were detected in samples from producer $\mathrm{A}, \mathrm{B}$, and $\mathrm{D}$, while it was not found at producer C (Table 1). Saleh-Lakha et al. [36] reported that more than $5.5 \%$ of moderately temperature-abused products (store at $7{ }^{\circ} \mathrm{C}$ ) were found to contain $>10^{5} \mathrm{CFU} / \mathrm{ml}$

Table 1 Effects of PEF process to reduce microbe contamination in milk

\begin{tabular}{|c|c|c|c|c|c|c|c|}
\hline Producers & Process & $\begin{array}{l}\text { TPC } \\
\text { (colony/ml) }\end{array}$ & $\begin{array}{l}\text { MPN } \\
\text { Enterobacter } \\
\text { (MPN/ml) }\end{array}$ & $\begin{array}{l}\text { Salmonella spp. } \\
\text { (qualitative) }\end{array}$ & S. aureus & B. cereus & $\begin{array}{l}L . \\
\text { monocytogenes } \\
\text { (qualitative) }\end{array}$ \\
\hline \multirow[t]{4}{*}{ A } & Raw milk & $>3 \times 10^{7}$ & $>110$ & V & $4 \times 10^{5}$ & $2.7 \times 10^{3}$ & Less than 1 \\
\hline & Heating $\left(60^{\circ} \mathrm{C}\right)$ & $4.7 \times 10^{2}$ & $<0.3$ & Less than 1 & $4.8 \times 10^{1}$ & $1.3 \times 10^{3}$ & Less than 1 \\
\hline & PEF & less than 1 & $<0.3$ & Less than 1 & 8.5 & $9.3 \times 10^{2}$ & Less than 1 \\
\hline & Cooling (50 oC) & $7.1 \times 10^{1}$ & $<0.3$ & Less than 1 & $5.1 \times 10^{1}$ & $2.6 \times 10^{3}$ & Less than 1 \\
\hline \multirow[t]{4}{*}{ B } & Raw milk & $2.5 \times 10^{7}$ & 12 & V & $>3 \times 10^{6}$ & $<100$ & Less than 1 \\
\hline & Heating $\left(74^{\circ} \mathrm{C}\right)$ & $2.6 \times 10^{3}$ & $<0.3$ & Less than 1 & $6.3 \times 10^{1}$ & $4.5 \times 102$ & Less than 1 \\
\hline & $\operatorname{PEF}(50 \mathrm{kV}, 10 \mathrm{~s})$ & $3.5 \times 10^{4}$ & $<0.3$ & Less than 1 & less than ${ }^{1}$ & $5.8 \times 102$ & Less than 1 \\
\hline & Cooling $\left(50^{\circ} \mathrm{C}\right)$ & $2.8 \times 10^{4}$ & $<0.3$ & Less than 1 & less than ${ }^{1}$ & $7.2 \times 101$ & Less than 1 \\
\hline \multirow[t]{6}{*}{ C } & Raw milk & $2.3 \times 10^{6}$ & $>110$ & Less than 1 & $2.8 \times 10^{3}$ & less than 1 & Less than 1 \\
\hline & Heating $\left(60^{\circ} \mathrm{C}\right)$ & $7.8 \times 10^{6}$ & $>110$ & Less than 1 & $4.9 \times 10^{5}$ & less than 1 & Less than 1 \\
\hline & PEF 1 & $3.5 \times 10^{5}$ & $>110$ & Less than 1 & $2.5 \times 10^{5}$ & less than 1 & Less than 1 \\
\hline & $\operatorname{PEF} 2\left(55^{\circ} \mathrm{C}\right)$ & $1.5 \times 10^{5}$ & $>110$ & Less than 1 & $2.4 \times 10^{3}$ & less than 1 & Less than 1 \\
\hline & $\operatorname{PEF} 3\left(60^{\circ} \mathrm{C}\right)$ & $4.6 \times 10^{3}$ & 2.3 & Less than 1 & $2.1 \times 10^{2}$ & Less than 1 & Less than 1 \\
\hline & Mixing $\left(50^{\circ} \mathrm{C}\right)$ & $<4$ & $<0.3$ & Less than 1 & $1.8 \times 10^{2}$ & Less than 1 & less than 1 \\
\hline \multirow[t]{3}{*}{ D } & Raw milk & $>3 \times 10^{7}$ & $>110$ & V & $3.4 \times 10^{5}$ & Less than 1 & Less than 1 \\
\hline & Thermal Pasteurization $\left(65-70^{\circ} \mathrm{C}\right)$ & $1.6 \times 10^{2}$ & $<0.3$ & Less than 1 & $6.3 \times 10^{0}$ & Less than 1 & Less than 1 \\
\hline & Cooling (room temperature) & $2 \times 10^{2}$ & 3.5 & Less than 1 & Less than 1 & Less than 1 & Less than 1 \\
\hline \multirow[t]{2}{*}{ E } & UHT milk & Less than 1 & Less than 1 & Less than 1 & less than 1 & Less than 1 & Less than 1 \\
\hline & UHT milk & Less than 1 & Less than 1 & Less than 1 & less than 1 & Less than 1 & Less than 1 \\
\hline
\end{tabular}




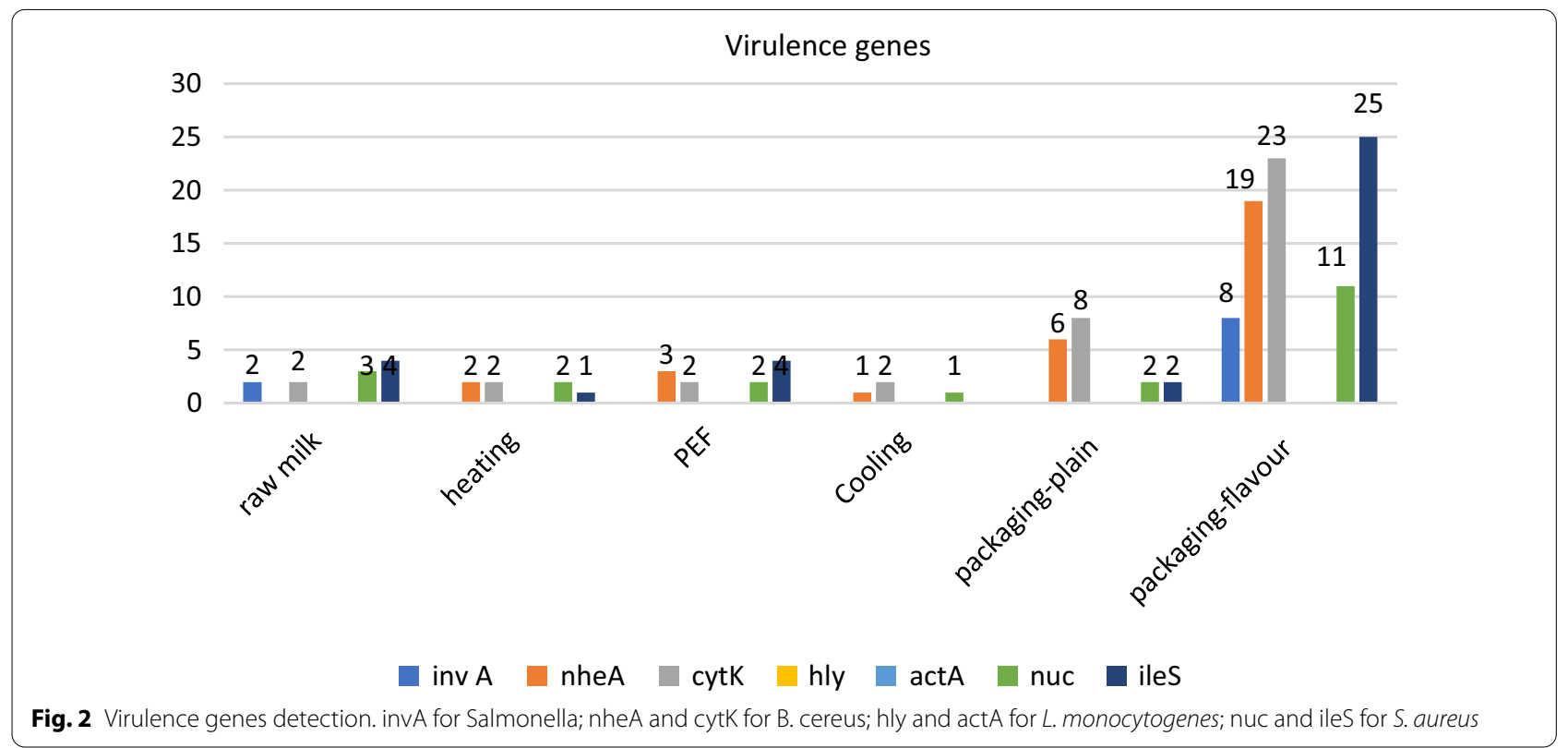

B. cereus. Amor et al. [5] reported that nheA (98.9\%) and cytK (37.9\%) were detected among B. cereus isolated from Tunisian foodstuffs.

Staphylococcus aureus specific gene nuc and ileS were detected in some milk samples as well as PCR detection from colonies (Fig. 2). S. aureus usually contaminate dairy products because it has a wide range living environment and can cause mastitis diseases which is still a problem in some dairy farms. Although L. monoctogenes specific gene hly and actA were not detected in all of samples, it can grow in refrigerated temperatures, which makes this organism a particular problem for food industry [37]. PEF producers must apply GMPs and follow recommendation guidelines of NACMF as an effort to create quality and safe products.

\section{Conclusion}

PEF has the potential to reduce microbial contamination in milk, but some microorganisms were resistant to PEF treatment. Combination of PEF with heating increase the efficacy. Monitoring of the quality need to be performed included post PEF treatment.

\section{Limitations}

Number of samples need to be increase. Effect of PEF on protein content have not been elaborated. PCR products need to be confirmed with DNA sequencing.

\section{Abbreviations}

SNI: Indonesian National Standard; DNA: Deoxyribonucleic acid; GMPs: Good Manufacturing Practices; NACMF: National Advisory Committee on Microbiological Criteria for Foods.

\section{Supplementary Information}

The online version contains supplementary material available at https://doi. org/10.1186/s13104-021-05805-3.

Additional file 1: Table S1. Primer sequences and PCR reactions.

Additional file 2: Table S2. Subset of significant difference in final products on each process.

\section{Acknowledgements}

The authors acknowledge support of Indonesian Food and Drug Authority and also thankful to Microbiology and Molecular Biology Division of National Quality Control of Drug and Food, Indonesian FDA for support research facilities.

\section{Authors' contributions}

SY and DW conceived the research concept and study design; DW and Y approved the proposal with some revision; SY carried out the research; SY and DW analyzed and interpreted the data, SY contributed in data collection and data analysis. SY and DW were involved in drafting and critically revising the manuscript. All authors read and approved the final manuscript.

\section{Funding}

This study was supported by Indonesian Food and Drug Authority. The funder has no contribution in design, collection, writing, and interpreting data in this study.

\section{Availability of data and materials}

The datasets used and/or analysed during the current study are available from the corresponding author on reasonable request.

\section{Declarations}

Ethics approval and consent to participate Not applicable.

Consent for publication

Not applicable. 


\section{Competing interests}

The authors declare that they have no competing interests.

\section{Author details}

${ }^{1}$ Indonesian Food and Drug Authority, Jalan Percetakan Negara No. 23, Jakarta Pusat 10560, Indonesia. ${ }^{2}$ Faculty of Biotechnology, Atma Jaya Catholic University of Indonesia, Jalan Jenderal Sudirman 51, Jakarta 12930, Indonesia.

\section{Received: 23 August 2021 Accepted: 10 October 2021}

\section{Published online: 26 October 2021}

\section{References}

1. World Health Organization. 2016. Burden of Foodborne Diseases in the South-East Asia Region. World Health Organization Regional Office for South-East Asia.

2. Oliver SP, Jayarao BM, Almeida RA. Foodborne pathogens in milk and the dairy farm environment: food safety and public health implications. Foodborne Pathog Dis. 2005;2:115-29.

3. Boor K, Wiedmann M, Murphy S, Alcaine S. A 100-year review: Microbiology and safety of milk handling. J Dairy Sci. 2017;100:9933-51. https:// doi.org/10.3168/jds.2017.12969.

4. Mthembu TP, Zishiri OT, El Zowalaty ME. Detection and molecular identifiction of Salmonella virulence genes in livestock production systems in South Africa. Pathogens. 2019;8:1-17. https://doi.org/10.3390/patho gens8030124.

5. Amor MGB, Jan S, Baron F, Grosset N, Culot A, Gdoura R, Gautier M, Techer C. Toxigenic potential and antimicrobial susceptibility of Bacillus cereus group bacteria isolated from Tunisian foodstuffs. BMC Microbiol. 2019:19:196. https://doi.org/10.1186/s12866-019-1571-y.

6. Zakrezewski AJ, Wierzchowska WC, Zadernowska A, Podlasz P. Virulence characterization of Listeria monocytogenes, Listeria innocua, and Listeria welshimeri isolated from fish and shrimp using in vivo early zebrafish larvae models and molecular study. Pathogens. 2020;9:1-10. https://doi. org/10.3390/pathogens9121028.

7. Andrade NC, Laranko M, Costa MM, Queiroga MC. Virulence factors in Staphylococcus associated with small ruminant mastitis: biofilm production and antimicrobial resistance genes. Antibiotis. 2021;10:1-18. https:// doi.org/10.3390/antibiotics10060633.

8. Abdulgader SM, Lentswe T, Whitelaw A, Foot MN. The prevalene and molecular mechanisms of mupirocin resistance in Staphylococcus aureus isolates from a hospital in Cape Town, South Africa. Antimicrob Resist Infect Control. 2020;9:1-7. https://doi.org/10.1186/s13756-020-00707-8.

9. Syed QA, Ishaq A, Rahman UU, Aslam S, Shukat R. Pulsed electric field technology in food preservation: a review. J Nutr Health Eng. 2017;6(6):00219.

10. Gleeson D, O'Connell A, Jordan K. Review of potential sources and control of thermoduric bacteria in bulk-tank milk. Irish J Agric Food Res. 2013;52:217-27.

11. Evrendilek GA. Non-thermal processing of milk and milk products for microbial safety. In: Ozer B, Evrendilek GA Eds. Dairy microbiology and biochemistry: Recent development. 1st edition. Boca Raton: CRC Press; 2014:322-355. doi:https://doi.org/10.1201/b17297.14

12. Andriawan $V$, Susilo B. Electric milking the high voltage-electric shock (Pulsed Electric Field) for milk pasteurization device using high voltage transformer and inverter. Jurnal Keteknikan Pertanian Tropis dan Biosistem. 2015;3(2):199-210.

13. Muslim C, Hawa LC, Argo BD. Pasteurization nonthermal of milk to inactive bacteria Staphylococcus aureus based Pulsed Electric Field (PEF) Jurnal Keteknikan Pertanian Tropis dan Biosistem. 2013;1 (1):35-49.

14. Al Mana H, Sundararaju S, Tsui CKM, Lopez AP, Yassine H, Al Thani A, Al Ansari K, Eltai NO. Whole-genome sequencing for molecular characterization of carbapenem-resistant Enterobacteriaceae causing lower urinary tract infection among pediatric patients. Antibiotics. 2021. https://doi org/10.3390/antibiotics10080972.

15. Indonesian Food and Drug Authority. 2019. Regulation Indonesian Food and Drug Authority number 13 about maximum limit of microbial contamination in processed food
16. Badan Standardisasi Nasional Indonesia. 2008. SNI 2897:2008: Metode pengujian cemaran mikroba dalam daging, telur dan susu, serta hasil olahannya.

17. International Standard Organization. 2007. ISO 7218: Microbiology of food and animal feeding stuffs - General requirements and guidance for microbiological examinations

18. International Standard Organization. 2004. ISO 21528-1: Microbiology of the food chain-horizontal method for the detection and enumeration of Enterobacteriaceae - part 1: Detection and enumeration by MPN technique with pre-enrichment.

19. Badan Standaridisasi Nasional. 2012. SNI ISO 7932:2012: Mikrobiologi bahan pangan dan pakan-Metode horizontal untuk enumerasi Bacillus cereus terduga - Teknik penghitungan koloni pada suhu $30^{\circ} \mathrm{C}$

20. Waturangi DE, Wennars M, Suhartono MX, Wijaya YF. Edible Ice in Jakarta, Indonesia, is contaminated with multidrug-resistant vibrio cholerae with virulence potential. J Med Microbiol. 2013:62:352-9.

21. Montanari C, Tylewicz U, Tabanelli G, Berardinelli A, Rocculi P, Ragni L, Gardini F. Heat-assisted pulsed electric field treatment for the inactivation of Sacharomyces cerevisiae: effects of the presence of citral. Front Microbiol. 2019:10:1737. https://doi.org/10.3389/fmicb.2019.01737.

22. Hawa LC, Susilo B, Jayasari NE. Comparison study on E. coli Inactivation and physical changes of thermal and non-thermal processing using PEF (Pulsed Electric Field) in fresh milk pasteurization. Jurnal Teknologi Pertanian. 2011;12(1):31-9.

23. Raso J, Frey W, Ferrari G, Pataro G, Knorr D, Teissie J, Miklavčič. D. Recommendation guidelines on the key information to be reported in studies of application of PEF technology in food and biotechnology process. Innov Food Sci Emerg Technol. 2016;3:312-21.

24. Pal M. Pulsed electric field processing: an emerging technology for food preservation. J Exp Food Chem. 2017;3:126. https://doi.org/10.4172/2472. 0542.1000126.

25. Ordoñez V, Carranza BV, Borroto ET, Rojas MT, Guerrero JAV, Dibarrat JA, Puigvert, F, Grille L, Revello AG, Pareja L. 2019. Microbial contamination in milk quality and health risk of the consumers of raw milk and dairy products. In Mozsik, G (Ed.), Nutrition in health and disease - Our challenges now and forthcoming time (pp. 1). Intechopen. . doi: https://doi.org/10. 5772/intechopen.77773

26. Martin NH, Boor KJ, Wiedmann M. Symposium review: effect of post-pasteurization contamination on fluid milk quality. J Dairy Sci. 2018;101:861-70. https://doi.org/10.3168/jds.2017.13339.

27. Food and Drug Administration. 2000. Kinetics of microbial inactivation for alternative food processing technologies. A report of The Institute of Food Technologists for the Food and Drug Administration of the U.S. Department of Health and Human Services.

28. Quigley L, O'Sullivan O, Stanton C, Beresford TP, Ross RP, Fitzgerald GF, Cotter PD. The complex microbiota of raw milk. FEMS Microbiol Rev. 2013;37:664-98. https://doi.org/10.11111/1574-6976.12030.

29. Cebrián G, Mañas P, Condón S. Comparative resistance of bacterial foodborne pathogens to non-thermal technologies for food preservation. Front Microbiol. 2016;7:734. https://doi.org/10.3389/fmicb.2016.00734.

30. Liwan SY, Budiarso TY. Monitoring of pollution of Salmonella sp. In raw milk using virulence gen marker. Indonesian Food Nutr Progr. 2018;15(2):54-60. https://doi.org/10.22146/infp.33826.

31. Jassim AA, Al-Gburi NM. 2020. Virulence genes and antimicrobial resistance of Salmonella isolated from milk in Wasit Province, Iraq. Plant Archives 20(1): 2033-2039. e-ISSN: 2581-6003, ISSN: 0972-5210

32. Omar D, Al-Ashmawy M, Ramadan H, El-Sherbiny M. Occurrence and PCR identification of Salmonella spp. From milk and dairy products in Mansoura, Egypt. Int Food Res J. 2018;25(1):446-52

33. Fagerlund A, Lindbäck T, Granum PE. Bacillus cereus cytotoxins Hbl, Nhe and CytK are secreted via the Sec translocation pathway. BMC Microbiol. 2010:10:304. https://doi.org/10.1186/1471-2180-10-304.

34. Zhang Z, Feng $L, X u H$, Liu C, Shah NP, Wei H. Detection of viable enterotoxin-producing Bacillus cereus and analysis of toxigenicity from ready-to-eat foods anf infant formula milk powder by multiplex PCR. J DDairy Sci. 2015:99:1047-55. https://doi.org/10.3168/jds.2015-10147.

35. Lindbäck T, Fagerlund A, Rødland MS, Granum PE. Characterization of the Bacillus cereus Nhe enterotoxin. Microbiology. 2004;150:3959-67. https:// doi.org/10.1099/mic.027359-0. 
36. Saleh-Lakha S, Leon-Velarde CG, Chen S, Lee S, Shannon K, Fabri M, Downing G, Keown B. A study to assess the numbers and prevalence of Bacillus cereus and its toxins in pasteurized fluid milk. J Food Prot. 2017;80(7):1085-9. https://doi.org/10.4315/0362-028X.JFP-16-521.

37. Food and Drug Administration. 2012. Bad bug book. Foodborne pathogenic microorganisms and natural toxins. Second edition

\section{Publisher's Note}

Springer Nature remains neutral with regard to jurisdictional claims in published maps and institutional affiliations.
Ready to submit your research? Choose BMC and benefit from:

- fast, convenient online submission

- thorough peer review by experienced researchers in your field

- rapid publication on acceptance

- support for research data, including large and complex data types

- gold Open Access which fosters wider collaboration and increased citations

- maximum visibility for your research: over $100 \mathrm{M}$ website views per year

At BMC, research is always in progress.

Learn more biomedcentral.com/submissions 